\title{
Verification of the Passive House Concept to the South of Brazil Climate
}

\author{
Renata Dalbem ${ }^{1}$, Stifany Knop ${ }^{1}$, Eduardo Grala da Cunha ${ }^{1}$, Rui F. Oliveira ${ }^{2}$, Maria Fernanda Rodrigues ${ }^{2}$ and \\ Romeu Vicente ${ }^{2}$ \\ 1. Laboratory of Comfort and Energy Efficiency, Faculty of Architecture and Urbanism, Federal University of Pelotas, Pelotas \\ 96010-020, Brazil \\ 2. Civil Engineering Department, University of Aveiro, Aveiro 3810-193, Portugal
}

\begin{abstract}
The high impact of the building's sector on energy consumption and on the environment has led to increased concerns on the performance of indoor thermal buildings, and led many countries to define stricter requirements for their building legislation. In 2010 , the European Union has established that by the end of 2020 all new buildings must have energy consumption close to zero (NZEBs (nearly zero energy buildings)), increasing the pursue for more efficient building design. One way to achieve buildings with low energy consumption while maintaining a high thermal comfort is the passive house concept. The paper presents an architectural project designed to meet the Passive House requirements for the climate of southern Brazil. The energy balance was carried out using the energy balance tool-PHPP (passive house planning package), that verified the compliance of the prerequisites required for certification, which are related to the primary energy consumption, heating, cooling demand and overheating rate of the building.
\end{abstract}

Key words: Energy efficiency, NZEB, passive house, sustainability.

\section{Introduction}

In Brazil, according to the BEN, 2014 (National Energy Balance), buildings are responsible for $50 \%$ of consumption of electricity. The residential sector is the largest consumer, accounting for $24.9 \%$, followed by the commercial sector with $17.1 \%$ and the public sector with $8 \%$ [1].

In residential buildings, $27 \%$ of energy consumption is associated to refrigeration equipment (refrigerator and freezer), $24 \%$ to water heating, $20 \%$ to the use of air conditioning, $14 \%$ to lighting and $15.5 \%$ represent other appliances and equipments [2].

In Brazil, concerns on the energy efficiency of buildings increased after the energy sector crisis, occurred in 2001. In October of that year, it was published the Law 10295, which sets national policies on the conservation and rational use of energy in the

Corresponding author: Renata Dalbem, master candidate, research fields: energy efficiency, passive house, NZEB and sustainability. buildings [3]. In December of the same year, came into force the Decree 4059, regulating Law 10295, which established maximum limits of energy consumption, minimum energy efficiency labelling of equipment sold in Brazil for building acclimatization [4].

In 2005, it was approved the first Brazilian standard for building thermal performance, NBR 15220; the standard presents calculations methods of thermal transmittance ( $U$-value), thermal capacity, thermal delay and solar factor of the components, constructive guidelines and bioclimatic strategies for social housing, associated to the Brazilian bioclimatic zoning [5]. Then in 2008, the NBR 15575 was published in order to evaluate the performance of residential buildings and set 13 aspects to be considered during the analysis of the building, including thermal performance. This standard was updated in 2013, when it effectively entered into practical application [6].

In 2007, it was published the first energy efficiency regulations for commercial buildings and public 
services (RTQ-C (Technical Quality Requirements for Energy Efficiency Level in Commercial, Public and Service Buildings)), that specifies the technical requirements and methods for classification of buildings for energy efficiency. The RTQ-C had its first update in 2009 when it was effectively published [7]. Then, in 2010, it was published the first regulation for residential buildings (RTQ-R) [8]. The two regulations classify buildings on a scale ranging from "A" (highest efficiency) to "E" (lowest efficiency).

The Label A level became mandatory for federal public buildings, with $500 \mathrm{~m}^{2}$ or more (new or retrofit buildings), since 2014. It is expected that in a few years it will be mandatory for all buildings [9].

Although past events have resulted in actions for energy efficiency in buildings, there is still a long way to be followed for the country to achieve significant results in this field.

In the European Union, with the recast Directive 2010/31/EU on the energy performance of buildings it was established updated goals to be achieved by member states by the end of 2018, that all new public buildings, occupied or owned, should be NZEB (nearly zero energy buildings), and by the end of 2020, this target is to be extended to all new buildings [10].

One way to more easily achieve buildings NZEBs is the implementation of the passive house concept, which combines passive solutions with current technological standards and some effective control tools to ensure high indoor comfort and energy saving [11].

In this context, there is no doubt that Europe is trailing an ambitious path, at a much higher level than Brazil. However, it is essential to consider that the recent advances in Brazil, will be increasing at some point, will lead to regulations or guidelines for NZEB buildings.

This paper targets the analysis of a residential building located in the climate context of southern Brazil-Bioclimatic Zone 2 (ZB2), in compliance with the requirements passive house. The climate is characterized as subtropical, where the four seasons are well defined, presenting heating demand as well as cooling demand to maintain good indoor comfort conditions during the summer, avoiding overheating.

\section{Method}

The study was conducted in three main stages:

- First, it was carried out a literature review in order to understand the concepts of passive house for application design;

- In the second stage, it was developed a residential architectural design in accordance to the five basic principles of the passive house standard, adapted to the climate of Pelotas. This adaptation was based on studies developed for hot climates in Europe, the Passive-On project [13]. Still in the second stage, the energy balance of the building was verified using the tool PHPP (passive house planning package);

In the third stage, the results of the research were analyzed.

\section{Literature Review}

A passive house building is designed and built respecting five design principles:

- thermal insulation;

- thermal bridges free design;

- airtightness;

- mechanical ventilation with heat recovery;

- efficient windows.

The thermal building envelope is essential to maintain the indoor comfort. The high insulation of the building prevents the indoor heat losses, excessive energy consumption for heating and maximizes thermal inertia [14].

The standard passive house requires that all envelope elements have a low thermal transmittance value ( $U$-value), which is recommended to be lower than $0.15 \mathrm{~W} / \mathrm{m}^{2} \mathrm{~K}$ for all opaque exterior elements [12]. Depending on weather conditions and the building design, the thickness need of for the insulation level may vary. In mild climates, the thermal transmittance 
( $U$-value) may take values in the range of $0.20 \sim 0.30 \mathrm{~W} / \mathrm{m}^{2} \mathrm{~K}$ [12].

Thermal bridges should be avoided or minimized, in order to prevent additional linear and punctual energy loss. passive house certification recommends that all thermal bridges must have a value psi $(\Psi)$ lower than $0.01 \mathrm{~W} /(\mathrm{mK})$ [14].

To meet comfort conditions, the thermal transmittance of a window-which includes loss through glass, frame and spacers of glass panes - ranges from a minimal recommended value 0.8 to $1.0 \mathrm{~W} / \mathrm{m}^{2} \mathrm{~K}$. Windows must also have a balanced solar factor, recommended to be greater than $50 \%$. The calculation of the heat transfer coefficient of a miter takes into account the characteristics of glass, the window frames and installation, which should result in a thermal transmittance lower than $0.85 \mathrm{~W} / \mathrm{m}^{2} \mathrm{~K}$ [11].

The building must be airtight, proven by a blower door test result of less than 0.6 ACH (air changes per hour) at a pressure difference of $50 \mathrm{~Pa}$. Unwanted air leakage can significantly increase the heating requirement of a dwelling, causing local discomfort due to draft and possibly cause moisture formation inside building structure and component interfaces. To achieve airtightness in place requires the use of appropriate membranes, to form a continuous airtight barrier [14].

It must be specified a MVHR (mechanical ventilation with heat recovery equipment). The heat recovery efficiency should be higher than $75 \%$ and should certified by PHI (passive house institute) component database. The heat exchanger does not mix the fresh air that enters with the exhaust air, it simply performs heat exchange to reduce the need for heating demand [14]. The system should be sized to ensure a minimum air flow of $30 \mathrm{~m}^{3} / \mathrm{h}$ of air per person in residential buildings, ensuring hygienic comfort [11].

Passive house buildings must meet very strict requirements regarding its design and construction and are certified based on a quality check of its project and execution. The requirements of the German standard consist of [15]:

(1) Heating criterion: the useful energy demand for space heating does not exceed $15 \mathrm{kWh} / \mathrm{m}^{2} \mathrm{y}$ or the heating load should not exceed $10 \mathrm{~W} / \mathrm{m}^{2}$;

(2) Cooling criterion: the useful energy demand for space cooling does not exceed $15 \mathrm{kWh} / \mathrm{m}^{2} \mathrm{y}$ or the cooling load should not exceed $10 \mathrm{~W} / \mathrm{m}^{2}$;

(3) Primary energy criterion: the primary energy demand for all energy services, including heating, domestic hot water, auxiliary and household electricity, does not exceed $120 \mathrm{kWh} / \mathrm{m}^{2} \mathrm{y}$;

(4) Airtightness criteria: the building envelope must have a pressurization test result according to EN 13829 of no more than $0.6 \mathrm{~h}^{-1}$;

(5) Overheating criteria: thermal comfort must be met for all living areas during winter as well as in summer, with not more than $10 \%$ of the hours in a given year over $25^{\circ} \mathrm{C}$.

The Passive-On project was the first attempt for a critical revision of the adaptability and application of the standard passive house in warm climates in southern Europe taking into account the climatic data [13].

According to studies, in locations with design conditions at temperatures above $0{ }^{\circ} \mathrm{C}$, a pressurization test result of $1.0 \mathrm{ACH}$ is usually enough to achieve the heating criterion [12].

In the warm season, the Passive-On sets the maximum indoor temperature to $26{ }^{\circ} \mathrm{C}$, for the overheating criteria [12].

\section{Architectural Design}

\subsection{Climatic Data}

Climatic data of Pelotas was obtained from agrometeorological EMBRAPA (Brazilian Agricultural Research Corporation) database, in Capão do Leão, campus of the Federal University of Pelotas, collected between 1971 2000.

Pelotas lies at the coordinate of latitude $31^{\circ} 08^{\prime} \mathrm{S}$, and coordinate of longitude $52^{\circ} 03^{\prime} \mathrm{W}$, and its altitude is $82.5 \mathrm{~m}$, with humid subtropical climate. In the 
summer the maximum temperatures vary between $22.9{ }^{\circ} \mathrm{C}$ and $28.2{ }^{\circ} \mathrm{C}$, and shows minimal winter temperatures between $8.6{ }^{\circ} \mathrm{C}$ and $11.2{ }^{\circ} \mathrm{C}$. January which is the hottest month with an average temperature of $23.2{ }^{\circ} \mathrm{C}$ and relative humidity of $77.4 \%$. July, the coldest month of the year, its average temperature is $12.3{ }^{\circ} \mathrm{C}$ and relative humidity is $84.9 \%$ [16].

\subsection{General Aspects}

The architectural design of the building was developed based on passive strategies used in the design of bioclimatic house of Pouey [17] and following the compliance criteria required by the standard passive house. It is a detached house, to be built next to the Campus Porto of the Federal University of Pelotas, Brazil.

Fig. 1 shows that the residence has $126.45 \mathrm{~m}^{2}$ and consists of two floors: (1) the kitchen and integrated living room, sun room, two bedrooms and bathroom are on the ground floor; (2) the workspace, technical area and small toilet are on the second floor. The project also includes a garage for one car (outside the thermal envelope). The north orientated solarium, is totally translucent (walls and roof) with operable sun protection on the roof that allows to take advantage of the sunlight gains for passive heating in winter and shading in summer. It can also be opened to allow natural ventilation to cool down during the summer.
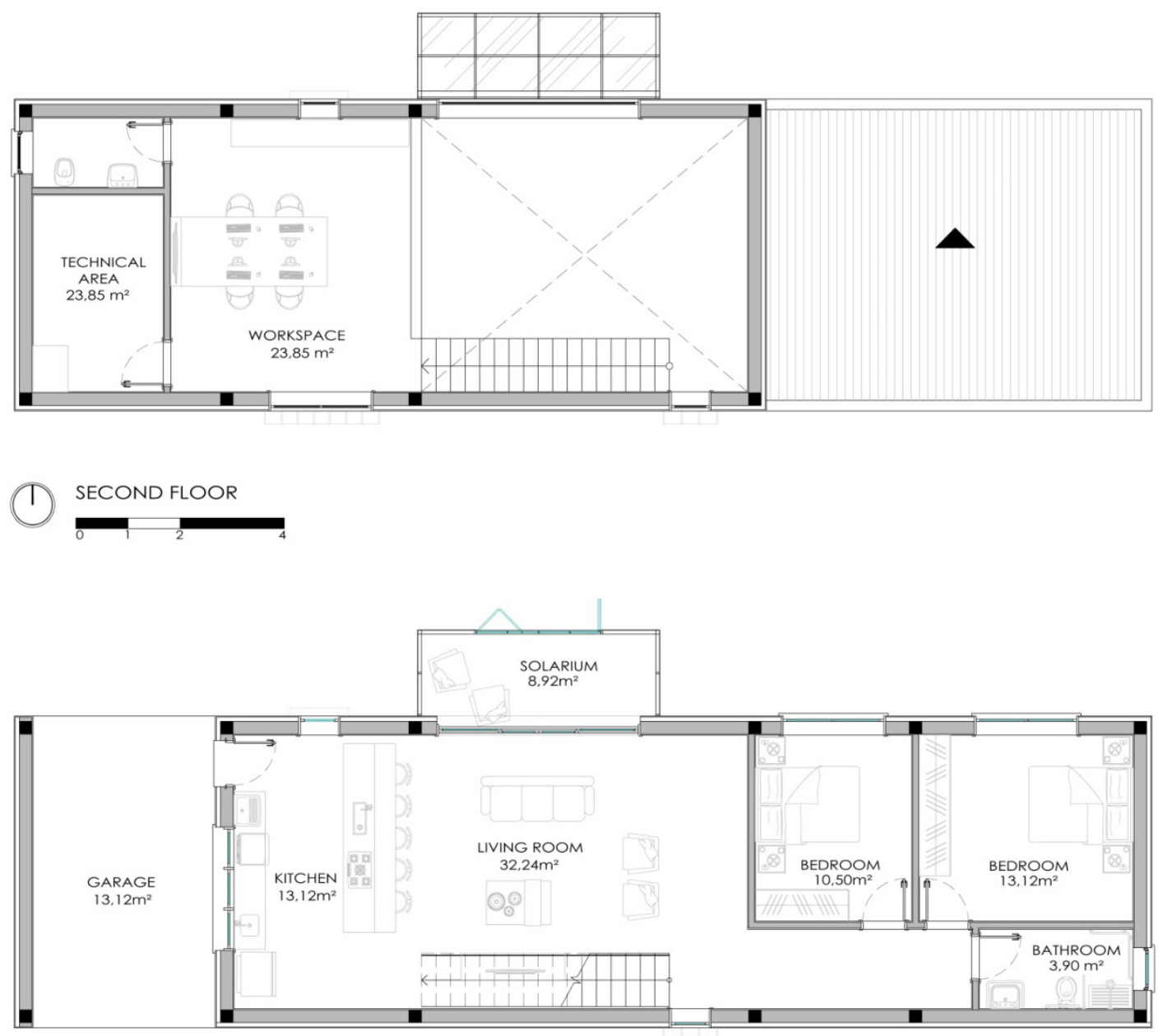

1) GROUND FLOOR

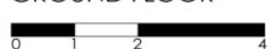

Fig. 1 Architectural project-second floor to first floor. 
The project was oriented to the east/west axis, maximizing the north facade, thereby increasing solar radiation gains in winter, and lower sun gains to the east and west facades, reducing undesirable gains in summer. The glazed area corresponds to $24 \%$ of the opaque area of the building. The opening percentage in the northern facade is $24.95 \%, 5.93 \%$ south, $1.97 \%$ east and $5.91 \%$ west (southern hemisphere). All windows have external sun protection shading devices.

\subsection{Thermophysical Properties of the Opaque Envelope}

The construction elements of the building were adopted in order to meet the requirements of the passive house standard, where the $U$-value recommended for hot climates should be close to 0.30
$\mathrm{W} /\left(\mathrm{m}^{2} \mathrm{~K}\right)$, for all elements of the opaque envelope [12]. Tables 2-5 show the thermal properties of the materials used and the results of the total thermal transmittance coefficient ( $U$-value) of the external building elements, whereas the internal and external surface resistances $\left(R_{s i}\right.$ and $R_{s e}$ ) according to NBR 15220 [5].

\subsection{Windows}

The adopted windows consist of double glazing composed of glass pane Planitherm Ultra N 6 mm, air layer $14 \mathrm{~mm}$ and glass pane Planilux $6 \mathrm{~mm}$, with a solar factor (g) of 0.57 and $U$-value of $1.5 \mathrm{~W} /\left(\mathrm{m}^{2} \mathrm{~K}\right)$. The frame is PVC (polyvinyl chloride), white, and the $U$-value $\left(U_{\text {frame }}\right)$ is $1.5 \mathrm{~W} /\left(\mathrm{m}^{2} \mathrm{~K}\right)$. The windows have external sun protection devices to protect from direct sun radiation in summer (external roller blind).

Table 1 Climatic data for Pelotas, Rio Grande do Sul, Brazil.

\begin{tabular}{|c|c|c|c|c|c|c|c|c|c|c|c|c|}
\hline Pelotas & Jan. & Feb. & Mar. & Apr. & May & Jun. & Jul. & Aug. & Set. & Oct. & Nov. & Dec. \\
\hline Ambient temp. $\left({ }^{\circ} \mathrm{C}\right)$ & 23.2 & 23.0 & 21.7 & 18.5 & 15.1 & 12.4 & 12.3 & 13.4 & 14.9 & 17.5 & 19.6 & 22.0 \\
\hline North $\left(\mathrm{kWh} /\left(\mathrm{m}^{2}\right.\right.$ month $\left.)\right)$ & 91.0 & 74.0 & 56.0 & 39.0 & 26.0 & 21.0 & 21.0 & 29.0 & 41.0 & 60.0 & 84.0 & 100.0 \\
\hline East $\left(\mathrm{kWh} /\left(\mathrm{m}^{2}\right.\right.$ month $\left.)\right)$ & 151.0 & 126.0 & 99.0 & 71.0 & 49.0 & 38.0 & 41.0 & 56.0 & 77.0 & 110.0 & 145.0 & 161.0 \\
\hline South $\left(\mathrm{kWh} /\left(\mathrm{m}^{2}\right.\right.$ month $\left.)\right)$ & 106.0 & 113.0 & 122.0 & 116.0 & 101.0 & 86.0 & 88.0 & 99.0 & 104.0 & 106.0 & 105.0 & 103.0 \\
\hline West (kWh/(m²month)) & 151.0 & 126.0 & 101.0 & 71.0 & 49.0 & 38.0 & 41.0 & 56.0 & 77.0 & 110.0 & 145.0 & 161.0 \\
\hline Global $\left(\mathrm{kWh} /\left(\mathrm{m}^{2}\right.\right.$ month $\left.)\right)$ & 251.2 & 204.7 & 213.0 & 189.5 & 177.7 & 146.2 & 149.9 & 160.8 & 161.5 & 199.6 & 234.5 & 265.1 \\
\hline Dew point $\left({ }^{\circ} \mathrm{C}\right)$ & 18.7 & 19.0 & 17.9 & 15.1 & 12.1 & 9.4 & 9.6 & 10.4 & 11.6 & 13.6 & 15.0 & 17.2 \\
\hline Sky temp. $\left({ }^{\circ} \mathrm{C}\right)$ & 13.4 & 13.8 & 12.5 & 8.9 & 4.8 & 3.2 & 2.1 & 3.7 & 4.4 & 7.3 & 9.0 & 11.3 \\
\hline
\end{tabular}

Table 2 Layer constitutionof the external walls.

\begin{tabular}{|c|c|c|c|c|c|c|}
\hline \multicolumn{5}{|c|}{ External walls } & \multirow{2}{*}{$\begin{array}{l}R_{s i}=0.13 \\
R\left(\left(\mathrm{~m}^{2} \mathrm{~K}\right) / \mathrm{W}\right)\end{array}$} & \multirow{2}{*}{$\frac{R_{s e}=0.04}{U\left(\mathrm{~W} /\left(\mathrm{m}^{2} \mathrm{k}\right)\right)}$} \\
\hline & \multirow{5}{*}{ INT. } & Layers & $t(\mathrm{~m})$ & $\lambda(\mathrm{W} /(\mathrm{mK}))$ & & \\
\hline & & Interior plastering & 0.02 & 1.15 & 0.02 & \multirow{4}{*}{0.31} \\
\hline & & Thermal brick-weber & 0.24 & 0.22 & 1.07 & \\
\hline \multirow[b]{2}{*}{ EXT. } & & $\begin{array}{l}\text { Thermal insulation-EPS } \\
\text { (expanded polystyrene) }\end{array}$ & 0.08 & 0.04 & 2.00 & \\
\hline & & Exterior render & 0.02 & 1.15 & 0.02 & \\
\hline
\end{tabular}

Note: $t=$ thickness; $\lambda=$ thermal conductivity; $R=$ thermal resistance; $U=$ thermal transmittance coefficient.

Table 3 Layer constitution of the thermal bridges.

\begin{tabular}{|c|c|c|c|c|c|c|}
\hline \multicolumn{5}{|c|}{ Thermal bridges } & \multirow{2}{*}{$\frac{R_{\mathrm{si}}=0.13}{R\left(\left(\mathrm{~m}^{2} \mathrm{~K}\right) / \mathrm{W}\right)}$} & \multirow{2}{*}{$\frac{R_{\mathrm{se}}=0.04}{U\left(\mathrm{~W} /\left(\mathrm{m}^{2} \mathrm{k}\right)\right)}$} \\
\hline \multirow[b]{5}{*}{ EXT. } & & Layers & $t(\mathrm{~m})$ & $\lambda(\mathrm{W} /(\mathrm{mK}))$ & & \\
\hline & & Interior plastering & 0.02 & 1.15 & 0.02 & \multirow{4}{*}{0.43} \\
\hline & & Concrete pillars/beams & 0.24 & 1.75 & 0.14 & \\
\hline & & Thermal insulation-EPS & 0.08 & 0.04 & 2.00 & \\
\hline & INT. & Exterior render & 0.02 & 1.15 & 0.02 & \\
\hline
\end{tabular}


Table 4 Layer constitution of the floor slab.

\begin{tabular}{|c|c|c|c|c|c|}
\hline \multirow[t]{2}{*}{ Floor slab } & & & & $R_{\mathrm{si}}=0.17$ & $R_{\mathrm{se}}=0.17$ \\
\hline & Layers & $t(\mathrm{~m})$ & $\lambda(\mathrm{W} /(\mathrm{mK}))$ & $R\left(\left(\mathrm{~m}^{2} \mathrm{~K}\right) / \mathrm{W}\right)$ & $U\left(\mathrm{~W} /\left(\mathrm{m}^{2} \mathrm{k}\right)\right)$ \\
\hline 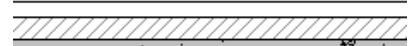 & Ceramic coating & 0.01 & 0.90 & 0.01 & \multirow{4}{*}{0.40} \\
\hline 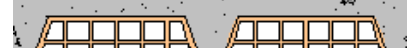 & Smoothing compound & 0.04 & 1.15 & 0.02 & \\
\hline 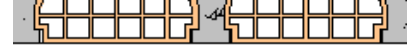 & Thermal insulation-EPS & 0.08 & 0.04 & 2.00 & \\
\hline & Prefabricated slab & 0.25 & - & 0.19 & \\
\hline
\end{tabular}

Table 5 Layer constitution of the roof.

\begin{tabular}{|c|c|c|c|c|c|}
\hline Roof & & & & $R_{\mathrm{si}}=0.10$ & $R_{\mathrm{se}}=0.10$ \\
\hline \multirow{3}{*}{ AR } & Layers & $t(\mathrm{~m})$ & $\lambda(\mathrm{W} /(\mathrm{mK}))$ & $R\left(\left(\mathrm{~m}^{2} \mathrm{~K}\right) / \mathrm{W}\right)$ & $U\left(\mathrm{~W} /\left(\mathrm{m}^{2} \mathrm{k}\right)\right)$ \\
\hline & Interior plastering & 0.02 & 1.15 & 0.02 & \multirow{4}{*}{0.41} \\
\hline & Prefabricated slab & 0.25 & - & 0.19 & \\
\hline \multirow{2}{*}{ 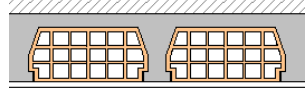 } & Thermal insulation-EPS & 0.08 & 0.04 & 2.00 & \\
\hline & Exterior render & 0.02 & 1.15 & 0.02 & \\
\hline
\end{tabular}

Table $6 \Psi$ values $(\mathrm{W} /(\mathrm{mK}))$.

\begin{tabular}{lll}
\hline Name & Thermal flux $(\mathrm{W} / \mathrm{m})$ & $\Psi \mathrm{W} /(\mathrm{mK})$ \\
\hline 1. Facade with underground ventilated space & 16.471 & -0.030 \\
2. Facade with intermediate floor slab & 16.588 & 0.054 \\
3. Facade with exterior & 27.038 & -0.279 \\
4. Facade in contact with garage space & 25.795 & 0.217 \\
5. Facade with second floor slab & 7.506 & -0.423 \\
6. Facade with roof slab (first floor) & 16.965 & 0.056 \\
7. Facade with roof slab & 21.231 & 0.028 \\
8. Corner wall angles & 16.369 & -0.089 \\
\hline
\end{tabular}

\subsection{Thermal Bridges}

Thermal bridges were calculated according to EN ISO 10211: 2007 [18]. It was used the THERM 7.3 ${ }^{\circledR}$ software for calculating the heat flux in 2D. Applying the standard calculation method, the following values of psi $(\Psi) \mathrm{W} /(\mathrm{mK})$ were obtained and are listed in Table 6.

\subsection{Mechanical Ventilation with Heat Recovery}

The building has a mechanical ventilation system with heat recovery, which exhausts polluted air from indoor spaces (kitchen, bathroom and toilet) and addict of the hot and supplies humid environments and breathes fresh air into the main permanence environments compartments (living room and bedrooms).

The mechanical ventilation system adopted for the project is the type ComfoAir 350 of Zehnder, with efficiency of $84 \%$ heat recovery, certified by PHI [19].

\subsection{Domestic Hot Water System}

Domestic hot water is produced resourcing to solar energy and natural gas. The system is composed of solar collectors and a hot water tank. The hot water demand considered for the project was 50 litres of each person, and the building occupation was calculated for an average of four persons.

\subsection{Shading}

In hot climates, the shading is important because it prevents the incidence of solar radiation into the building, reducing the inner overheating risks in summer.

The calculation of the total shading $\left(r_{s}\right)$ of the glass surfaces is performed with the worksheet "shading" in the PHPP tool. We can distinguish three types of shading:

- shading due to the building surfaces and window reveals; 
- shading due to near obstacles like overhangs, fins or venetian blinds;

- shading due to far obstacles, such as, other buildings in the surroundings.

The sun protection devices are designed to allow solar radiation into the building during winter and block out sun radiation in summer. Shading due to distant obstacles was not considered because the building is located in an open plot without neighbouring buildings.

The full shading factor $\left(r_{s}\right)$ which is a value for reducing solar gains of the glazed areas, was calculated for all the windows. For north oriented windows (southern hemisphere) the value was $43 \%$ for bedrooms, $47 \%$ for living room, $16 \%$ for the solarium door. For the south oriented windows the solar reduction factor was between $52 \%$ and $69 \%$ for the living room.

\subsection{Natural Ventilation in Summer}

The worksheet "SummVent" in the PHPP tools determines the renewal of indoor air in the summer provided by window operation (closing and opening).

Ventilation is carried out separately night and day, for having different schedules, temperature gradients (inside and outside temperature difference) and different wind speeds. For night ventilation is considered cross ventilation withwindow jambon opposite facades.

From PHPP, it is possible to estimate the air exchange contribution, for the night and daytime periods through natural ventilation. The air exchange by the windows is $0.27 \mathrm{ac} / \mathrm{h}$. As for the night ventilation, the exchange is $1.18 \mathrm{ac} / \mathrm{h}$. For night ventilation, all windows were considered open to allow greater heat exchange, for the hottest period of the year.

\section{Results and Discussions}

\subsection{Annual Heating Demand}

According to the thermal balance obtained using PHPP tool, the building envelope, namely external walls are responsible for $5.8 \mathrm{kWh} /\left(\mathrm{m}^{2} \mathrm{y}\right)$ of heat losses, the window frames for $4.6 \mathrm{kWh} /\left(\mathrm{m}^{2} \mathrm{y}\right)$, the roof for $4.4 \mathrm{kWh} /\left(\mathrm{m}^{2} \mathrm{y}\right)$ and the ground floor for $1.3 \mathrm{kWh} /\left(\mathrm{m}^{2} \mathrm{y}\right)$. The ventilation system, thermal bridges and external doors, is also responsible for heat losses, however of very low values in comparison with the latter.

Heat gains occur through solar gains through windows of $3.5 \mathrm{kWh} /\left(\mathrm{m}^{2} \mathrm{y}\right)$ and internal gains of $1.9 \mathrm{kWh} /\left(\mathrm{m}^{2} \mathrm{y}\right)$.

For the annual heating demand, the result obtained was $12.4 \mathrm{kWh} /\left(\mathrm{m}^{2} \mathrm{y}\right)$, and the maximum allowed by the passive house is $15 \mathrm{kWh} /\left(\mathrm{m}^{2} \mathrm{y}\right)$.

\subsection{Overheating}

To meet the certification compliance criteria, the frequency of overheating should not exceed $10 \%$ for the summer period. In addition, natural ventilation at night can significantly contribute for the cooling of building components.

Considering the natural ventilation strategy in the summer, and setting the maximum internal temperature to $26{ }^{\circ} \mathrm{C}$ (allowed for warmer climates), the result was $6.9 \%$ of overheating frequency and is lower than the allowable maximum limit.

\subsection{Primary Energy Demand}

The specific primary energy demand, which is the total energy to be used for all domestic applications (heating, hot water preparation and household electricity) was $103 \mathrm{KWh} /\left(\mathrm{m}^{2} \mathrm{y}\right)$, lower than the maximum limit allowed by certification that is $120 \mathrm{KWh} /\left(\mathrm{m}^{2} \mathrm{y}\right)$.

\subsection{Carbon Dioxide Emissions}

Emissions of greenhouse gas effect can be calculated from the final energy demands of the energy suppliers $\left(\mathrm{CO}_{2}, \mathrm{CH}_{4}, \mathrm{CO}\right.$, NMVOC, NOX and $\left.\mathrm{N}_{2} \mathrm{O}\right)$. The $\mathrm{CO}_{2}$ equivalent is defined as the global warming potential of each gas converted to equivalent amounts of $\mathrm{CO}_{2}$. The $\mathrm{CO}_{2}$ equivalent values are defined as the sum of the individual values of all energy sources. 
The total $\mathrm{CO}_{2}$ equivalent emissions generated by this building, was $26.5 \mathrm{kWh} / \mathrm{m}^{2} \mathrm{y}$ for passive house certification which is not established a limit on carbon dioxide emissions, but the PHPP spread sheets provide an estimation for this value.

\section{Conclusions}

The passive house concept was initially created for cold climates, such as in Central Europe. In milder climates, such as in southern Brazil, to meet the passive house compliance criteria becomes more difficult considering the assuring of good comfort conditions in the summer period, to prevent the building from overheating. It is possible meet the requirements for certification for Pelotas climate, therefore the present project is considered a pilot case study, using less stringent $U$-values for opaque envelope and glazed areas.

The application of the five passive house principles enables a significant reduction in energy consumption and ensures a high level of indoor comfort in buildings. To obtain good results, it is recommended the use of passive design strategies such as orientation of the building to the east/west axis, suitable building compactness and glazed areas to north facade. It is very important that the glazed areas are protected against the solar radiation in the warm periods in order to avoid the overheating.

In order to achieve the high energy performance of the building studied and to meet the passive house criteria, some changes were needed in the building system and equipment, such as the use of ventilation system with heat recovery and building envelope solutions with low $U$-values, very unlike Brazilian conventional construction practice and design.

\section{Acknowledgments}

The authors would like to express their thanks to the FAPERGS (Fundação de Amparo à Pesquisa do Estado do Rio Grande do $\mathrm{Su}$ ) that made possible the academic integration between Federal University of
Pelotas and Aveiro University.

\section{References}

[1] Empresa de Pesquisa Energética. 2015. Brazilian Energy Balance 2015 Year 2014. Rio de Janeiro: EPE.

[2] Lamberts, R., Dutra, L., and Perreira, F. O. R. 2001. Eficiência Energética na Arquitetura (Energy Efficiency in the Architecture). São Paula: ProLivros. (in Portugese)

[3] Official Gazette. 2001. Law No. 10295 of 17 October 2001: About the National Policy for Conservation and Rational Use of Energy. Brasilia: Official Gazette. (in Portuguese)

[4] Official Gazette. 2001. Decree No. 4059 of 19 December 2001. Brasilia: Official Gazette. (in Portuguese)

[5] Associação Brasileira de Normas Técnicas. 2005. NBR 15220: Thermal Performance for Social Interest Housing, Part 2: Calculation Method of Thermaltransmittance, Thermal Capacity, and Termal Lag of Building Componentes. Rio de Janeiro: ABNT. (in Portuguese)

[6] Associação Brasileira de Normas Técnicas. 2008. NBR 15575: Edifícios Habitacionais de até Cinco Pavimentos (Thermal Performance of Residential Buildings). Rio de Janeiro: ABNT.

[7] INMETRO (National Institute of Metrology, Standardization and Industrial Quality). 2013. Quality Technical Standards for Energy Efficiency Level in Commercial and Public Services Buildings. Brasília: Eletrobras. (in Portuguese)

[8] INMETRO (National Institute of Metrology, Standardization and Industrial Quality). 2012. Quality Technical Standards for Energy Efficiency Level in Residential Buildings. Brasília: Eletrobras. (in Portuguese)

[9] Brasil. 2014. "Normative Instruction MPOG/SLTI no 2." Accessed June 4, 2014. http://www.comprasgoverna mentais.gov.br/paginas/instrucoes-normativas/instrucao-n ormativa-no-2-de-4-de-junho-de-2014.

[10] Parlamento Europeu e Conselho da União Europeia. 2010. "Directive 2010/31/EU of the European Parliament and of the Council of 19 May 2010 on the Energy Performance of Buildings." Jornal Oficial da União Europeia 1 (53): 23-35.

[11] Wassouf, M. 2014. From de Passive House to the Standard Passive House: The Passive Architecture in Hot Climates. Barcelona: Gustavo Gili.

[12] Passive-On Project. 2007. "The Standard Passive House-Design Guidelines for Low Consumption Houses. Part I. Review of the Low Consumption Houses." Lisbon.

[13] Hacienda, C. D. E. Y., Industria, O. G. D., and Minas E. Y. 2011. "Guide of the Standard Passive House-Nearly 
Zero Energy Consumption Buildings." Fundación de la Energía de la Comunidad de Madrid. Accessed August 10, 2015. http://www.fenercom.com/pdf/publicaciones/Guiadel-Estandar-Passivhaus-fenercom-2011.pdf.

[14] McLeod, R., Mead, K., and Standen, M. n.d. "Passivhaus primer: Designer's Guide. A Guide for the Design Team and Local Authorities." Passive House BRE. Accessed August 2, 2016. http://www.passivhaus.org.uk/ filelibrary/Primers/KN4430_Passivhaus_Designers_Guid e_WEB.pdf.

[15] Passive House Institute. n.d. "Passive House Requirements." Passive House Institute. Accessed March 6, 2016. http://www.passiv.de/en/02_informations/02_ passive-house-requirements/02_passive-house-requireme nts.html.
[16] Estação Agroclimatológica de Pelotas (Capão do Leão). “Climate Normals.” EMBRAPA. Accessed May 8, 2016. http://agromet.cpact.embrapa.br/estacao/normais.html.

[17] Pouey J. A. 2011. "Residential Project for the Bioclimatic Zone 2 with Energy Modelling Analysis." Dissertation, PROGRAU-UFPel. Pelotas-RS.

[18] EN ISO 10211. 2007. Thermal Bridges in Building Construction-Heat Flows and Surface Temperatures-Detailed Calculations. Brussels: European Committee for Standardization.

[19] Passive House Institute. n.d. "Certificate Passive House Component." Passive House Institute. Accessed August 1, 2016. http://zehnderamerica.com/wpcontent/uploads/2015/05/ComfoAir-350-HRV-Passive-H ouse-Certificate.pdf. 